TEME, г. XLIV, бр. 1, јануар - март 2020, стр. 33-47

Оригинални научни рад $\quad$ https://doi.org/10.22190/TEME191115007C

Примљено: 15. 11. 2019

UDK 347.426

Ревидирана верзија: 5. 2. 2020.

347.5

Одобрено за штампу: 20. 2. 2020.

\title{
CAUSAL UNCERTAINTY: ALTERNATIVE CAUSATION IN TORT LAW ${ }^{a}$
}

\author{
Mihajlo Cvetković \\ University of Niš, Faculty of Law, Niš, Serbia \\ mihajloc@prafak.ni.ac.rs
}

\begin{abstract}
The causal link between the tortfeasor's unlawful act and the resulting damage is an essential element of tort liability. There are situations in tort law practice where singular damage has more than one potential cause, so it is important to determine which one is legally relevant. In those situations, it is hard for the claimant to identify the tortfeasor. Moreover, proving the causal link is difficult or almost impossible. On the contrary, the tortfeasor can successfully object that the damage cannot be attributed to him/her. European courts and doctrine have developed theories about alternative causation firstly by addressing asbestos litigation. This paper presents solutions from English, Belgian, French, German and Dutch tort law. Although they all strive for the same goal - fair compensation, the diversity of methods and outcomes is surprising. The end of the paper is devoted to the Principles of European Tort Law (PETL), where optimal suggestions on how to overcome causal uncertainty are presented.
\end{abstract}

Key words: tort, asbestos, cause, uncertainty, burden of proof.

\section{АЛТЕРНАТИВНИ КАУЗАЛИТЕТ У ОДШТЕТНОМ ПРАВУ}

\section{Апстракт}

Узрочна веза између штетникове противправне радње и штетне последице нужан је елемент деликтне одговорности. Пракса познаје ситуације када више потенцијалних узрока претходи једној штети, па је важно утврдити који од њих је правно релевантан. Тада оштећени тешко идентификује штетника, доказивање узрочне везе је тешко или немогуће, а штетник успешно приговара да му се штета не може приписати. Европски судови и доктрина развили су теорије о алтернативном каузалитету решавајући парнице поводом штета изазваних азбестом. У раду су приказана решења из енглеског, белгијског, француског, немачког и холандског одштетног пра-

${ }^{a}$ Рад је резултат истраживања на пројекту „Усклађивање права Србије са правом ЕУ” Правног факултета Универзитета у Нишу. 
ва. Мада сва она теже истом циљу - правичној накнади, изненађује разноликост и метода и исхода. Закључак је посвећен Принципима европског одитетног права (PETL), где су изведени оптимални предлози како превазићи каузалну несигурност.

Кључне речи: накнада, азбест, узрочна веза, последице, доказивање.

\section{INTRODUCTION}

Causal uncertainty forms a serious obstacle in tort law in general. Europe-wide, asbestos-related litigation provided significant developments regarding causation. In asbestos liability, the causation is challenging since more than one possible cause is present. From a medical point of view, it is inherently impossible to attribute a definite cause of individual cancer. Usually there are multiple sources of exposure, such as the workplace, environment and exposure originating from the victim. Moreover, conflicting scientific theories make this problem even greater. The question of causal uncertainty due to multiple sources of exposure lies at the heart of all cases under review.

\section{UNITED KINGDOM}

Landmark cases deliberating on causal uncertainty originate from the UK practice. Mr Fairchild had worked for a number of different employers, all of whom had negligently exposed him to asbestos. He died from mesothelioma (fatal cancer), and his wife was suing the employers (Fairchild v Glenhaven Funeral Services Ltd, 2002, UKHL 22). The problem was that a single asbestos fiber, inhaled at any time, can trigger mesothelioma. Moreover, the risk increases with exposure. Since it may take over 30 years before symptoms become evident, it was impossible to point to any single employer. "It was one of them", but it was impossible to say which one. Under the normal causation test, none of them would be liable. To overcome this, The House of Lords held that the appropriate test in this situation was whether the defendant had materially increased the risk of harm for the plaintiff. Thus was born so-called Fairchild exception, a deviation from the standard "but for" causation test. The employers were jointly and severally liable to the plaintiff (amongst themselves they could redress for different contributions).

Another cornerstone asbestos case was Barker (Barker v Corus (UK) plc, 2006). What distinguishes this case from Fairchild is that some exposures were not within the control of the defendant, and some employers were bankrupt. House of Lords decided that, in cases where there had been successive negligent exposure, the liability should be apportioned between defendants: each employer would be proportionally liable according to his contribution. 
Both in Fairchild and Barker there were multiple employerstortfeasors. In Fairchild, joint and several liability was promulgated. In Barker, the court stepped back from the far-reaching principle and embraced the proportional liability instead, so each employer was liable only for a fraction of compensation. However, proportional liability was abandoned by the English policymakers who returned to the Fairchild rule. Section 3 of the Compensation Act 2006 provided that mesothelioma victims who, due to the current state of medical science, were unable to prove whether the disease was caused by the wrongful exposure caused by the defendant or another source, were nonetheless entitled to compensation in respect of the totality of the harm suffered.

The third landmark, the Sienkiewicz case (Sienkiewicz v Greif, 2011), was different because the victims did not work for multiple employers. Rather, the disease was either caused by workplace exposure or by the background risk coming from miniscule atmospheric asbestos concentration (wrongful employers' behavior versus the natural factor). The court ignored the environmental exposure. One question raised in Sienkiewicz is whether the liability for the mesothelioma requires that the defendant doubled the background risk. The UK Supreme Court held that the material risk increase is enough. This was unorthodox because traditional standard of proof in civil English courts is the preponderance of the evidence: a defendant is liable if the plaintiff succeeds in establishing that it is more likely than not that the defendant caused concrete harm (Wagner, 2013, pp. 324).

The exposure was regarded as minor in Sienkiewicz. The defendant held that any work exposure had been minimal and far less than the environmental exposure. The breach of the employer's duty of care was found to have merely increased the (very small) risk of developing mesothelioma by only $18 \%$. However, the Supreme Court concluded that, as long as medical science is unable to demonstrate the exact mesothelioma origin, medical data were not a satisfactory basis for establishing liability. Therefore, where there is no known lower threshold of the exposure capable of causing mesothelioma, a very low level of asbestos must also be deemed sufficient, unless it is insignificant compared to other sources.

The Supreme Court endorsed that the Fairchild exception, which applies in "multiple exposure" mesothelioma cases - where the claimant was wrongly exposed by several defendants, also applies to "single exposure" cases (involving a single defendant and other non-tortious or environmental exposure). In the Sienkiewicz, the single defendant caused negligent limited exposure to asbestos, but environmental exposure was also present. The Supreme Court excluded conventional "balance of probabilities" test, and upheld the liability of the defendant. 


\section{BELGIAN LAW}

From the Belgian perspective, it is remarkable that the UK courts abandoned the conditio sine qua non test, in favor of the Fairchild exception. Moreover, civil liability actions for asbestos exposure are very rare because the system of compensation funds is implemented (Vandenbussche, 2017, p. 1147).

To assess the causal link, the Belgian courts use a "but for" or conditio sine qua non test. Once the sine qua non link is established, they apply the equivalence theory: all the causes are considered equal - direct or indirect, normal or abnormal, foreseeable or unforeseeable. In asbestos litigation, causation is the most difficult hurdle. It is very hard - if not impossible - to prove which exposure and during which employment period was the actual cause, i.e. conditio sine qua non. The same difficulty also arises in pollution cases or after major traffic accidents - it is uncertain which member from a tortfeasor group actually caused the harm. Belgian courts refuse to abandon the conditio sine qua non requirement in alternative causation cases. As a result, when damage is due to an unidentified member of a group, a plaintiff will fail to prove a causal link. This is unsatisfactory since the victim will receive no compensation. To overcome this injustice, different techniques have been developed (Vandenbussche, 2017, pp. 1142, 1143).

First of all, the conditio sine qua non test can be bridged by vicarious liability. A judge can attribute liability to a custodian, parent, principal or teacher without identifying the actual wrongdoer. For example, a fire broke out at the company room where employees were allowed to smoke. The employer was held liable for the damage, although the actual fire-starter was unknown. As all potential tortfeasors were employees, it was not necessary to identify the real one (Vandenbussche, 2017, pp. 1144).

Secondly, there is a specific liability regime for multiple traffic collisions. When several vehicles are involved and it is impossible to determine who was responsible, the damage compensation will be equally distributed among the drivers' insurers, unless one can prove that "the concrete driver" is certainly not involved. This rule adopts vicarious joint and several liability, accompanied by the reversal of the burden of proof. The victim can sue each of the insurers for the entire harm (Vandenbussche, 2017, pp. 1144).

Thirdly, there is a judicial technique to overcome causal uncertainty. If we consider a group of potential tortfeasors to have been acting in concert (where a pact between members to commit a tort is presumed), all participants are held jointly and severally liable, so there is no longer the need to identify the actual tortfeasor(s): For example, four children are throwing stones to each other. The fifth boy, while running away from this activity is hit. The four children deny having thrown the fatal stone 
and the boy cannot prove who is lying. All the children were playing a dangerous game, so the actual cause was not the individual harmful act, but their joint participation. Therefore, their parents are jointly and severally liable (Vandenbussche, 2017, pp. 1145). However, those techniques are unhelpful when several potential wrongdoers are unrelated to each other, such as in the asbestos cases.

Fourthly, the judge can also use evidentiary mechanisms to overcome causal uncertainty, such as presumptions of fact. This is a solution where the number of potential tortfeasors is limited and the circumstances are pointing at one of them. For example, a house situated near two quarries was hit by stones after excavation explosions. The victim could not prove which quarry was responsible. The judge dismisses the joint and several liability because the stones could only originate from one single quarry, and presumes as a fact that the damage was caused by the quarry closer to the house (Vandenbussche, 2017, pp. 1146).

Another similar mechanism is the judicial burden of proof reversal. A pedestrian was run over by a negligent car driver and afterwards was hit again by a second car. The court decides that the individual car driver can only be exculpated if he prove that his act was not the cause of death (in standard practice, the claimant needs to establish a causation) (Vandenbussche, 2017, pp. 1146).

\section{FRENCH LAW}

French courts use presumptions and probabilities in alternative causation cases. "DES" litigation is illustrative of this. The plaintiffs' mothers had taken the DES drug while pregnant, and experts revealed this to be a proximate cause of reproductive tract cancers in the plaintiffs. Years later, victims were unable to identify the specific company that sold the pills absorbed by their mothers, since various producers made DES. Therefore, the defendant was unidentifiable. The Cour de cassation thus decided to reverse the burden of proof. If the claimant proves that damage resulted from DES, then she can be compensated by any or even by all DES manufacturers, in solidum. To avoid liability, the manufacturer must prove that his pills did not cause the harm, which is almost impossible. Nonetheless, the manufacturer who compensated the victim has a recourse action against other manufacturers. According to the first instance court, the compensation should be spread equally among the manufacturers. This solution was unfair because the market shares were different: one manufacturer had a $97 \%$, whereas the other one had only $3 \%$. The Second instance court rejected the first solution and ruled that each contribution should be determined according to the market share. In short, the DES litigation imposed proportional liability between tortfeasors (G'Sell, 2017, pp. 1111). 
The French Project of Reform of Tort Liability at art. 1240 provides the burden of proof reversal in case of multiple possible defendants. It also stipulates the liability in solidum of all defendants toward the victim, and provides apportionment rules based on the probability that each defendant caused the harm (G'Sell, 2017, p. 1112). "Full compensation" is an essential principle of the French Tort Law. Therefore, the courts and the legislator favor reversing the burden of proof and liability in solidum on every possible wrongdoer (G'Sell, 2017, pp. 1113).

However, a recent development has shown that the Cour de cassation does not want to apply the same reasoning to all cases with alternative causation. In one case, a surgical compress was left in the abdomen of a patient who had undergone two similar surgical procedures in two different clinics. The patient sued two surgeons. Her claim was rejected since she was unable to determine which surgeon had negligently forgotten the compress (G’Sell, 2017, pp. 1111).

Regarding asbestos, the French government created a fund for the early retirement in 1999. The acceptance of the fund's compensation impedes any subsequent legal claims against the employer. The fund always files a recourse action when the employer commits an inexcusable negligence. If several employers commit something wrong, but it is impossible to determine which one caused the illness, then the fund recovers against employers in proportion to the actual duration of the employee's exposure. The employer who paid the compensation also has a recourse action against other employers. The goal is to achieve full and easy compensation for asbestos victims (G'Sell, 2017, pp. 1113, 1114, 1115).

\section{GERMAN LAW}

Asbestos cases against employers never reach the civil courts since there is an operational public insurance compensation system. Assuming that this system did not exist, we may ask the question of how the German courts would deal with mesothelioma cases (Wagner, 2013, pp. 321).

Paragraph 830 BGB provides: (1) If more than one person has caused damage by a jointly committed tort, then each of them is responsible for the damage. The same applies if it cannot be established which of several persons involved caused the damage by his act (Wagner, 2013, pp. 326).

Under this provision, several defendants are responsible for the full damage. However, the Federal Supreme Court (BGH) holds that joint and several liability is limited to cases where each wrongful contribution was sufficient to cause the whole damage. The classic example: two hunters shoot in the woods and kill a victim, and it is impossible to determine who fired the fatal bullet; alternative causation from par. 830(1) BGB applies and both hunters are liable in full. Each contribution alone is 
sufficient to cause the full loss, but it remains unknown who the actual tortfeasor is. Another example: the husband of the deceased put five poisonous drops into her tea, her son added another five, and each dosage would have been lethal for the wife/mother (Wagner, 2013, pp. 327).

The BGH summarized the requirements for par. 830(1) application in three elements: (1) Each of the defendants must have committed a tort. The plaintiff needs to prove all the elements of delictual liability of every defendant, including wrongfulness, but excluding causation. (2) It is definitive that one of the defendants must have caused the harm. (3) Despite all evidence, it is impossible to establish who actually caused the harm (Wagner, 2013, pp. 327).

When individual contribution alone is not sufficient to cause the whole damage, it is argued that the individual tortfeasor should be held liable only in proportion to his contribution. There are two different theories. The traditional theory starts from the premise that par. 830 (1) BGB was designed to resolve causal uncertainty. Thus, that paragraph is not limited to cases where one victim confronts multiple potential tortfeasors, but should also govern situations of uncertainty whether the harm was caused by a single potential tortfeasor, on the one hand, and by the victim or by a natural cause, on the other hand. The size of the shares will be estimated by the court, taking into account the contributions and the gravity of the fault. When the victim or a natural cause is involved, the compensation will be proportionally reduced (Wagner, 2013, pp. 327-328).

The second theory for causal uncertainty takes inspiration from law and economics. If it is impossible to establish whether the harm was caused by A or B, or the victim or a natural cause, the law should avoid extreme solutions as claim rejection or full joint and several liability. Rather, each defendant should be held liable for a portion of the harm. The portion size should not be determined by causal contributions or even the gravity of fault, but rather by calculus. The share of any defendant should be equal to the likelihood of causing the harm (Wagner, 2013, pp. 328).

If the Sienkiewicz case had occurred in Germany, both theories would hold the defendant liable only for a portion of the loss. However, the calculation methods are different. The followers of the traditional approach would measure the contribution of the defendant against the natural causes (the background risk). In contrast, the followers of the lawand-economics approach would calculate the likelihood that it was the defendant who caused the harm (Wagner, 2013, pp. 328).

In Sienkiewicz, the background risk approximated 24 victims in 1 million people, while the employment pushed that number up to 28.34. The likelihood that a patient suffering from mesothelioma contracted the disease from a natural source is therefore 24 of 28.34 or $84.686 \%$, while the likelihood that the defendant had caused the disease was 4.34 of 28.34 or $15.314 \%$. Therefore, the compensation would be $15.314 \%$ of the 
damages (Wagner, 2013, pp. 328). The law-and-economics approach is attractive because it "calculates" the portion precisely.

However, there are downsides to proportional liability: the tort law compensatory function is not fulfilled; in high-profile and large-scale cases like mesothelioma, the social problem persists; the incentive for victims to bring action is greatly diminished if the potential reward is partial recovery only. This was the motivation for English lawmakers to abolish proportional liability, making way for full recovery (Wagner, 2013, pp. 329). We will see that the continental jurists have a different idea.

\section{ITALIAN LAW}

The main problem here are two conflicting scientific theories about mesothelioma. The "single fiber theory" claims that cancer is triggered by a single asbestos fiber, therefore subsequent exposures have no causative effect. On the contrary, the "multi-fiber theory" holds that accumulated asbestos fibers in the lungs jointly produce mutations. If the first theory is applied, the plaintiff must prove that the defendant exposed him to the fiber that triggered mesothelioma. The adoption of the second theory requires the plaintiff to prove that the defendant contributed to the exposure. These differences call for dual legal reasoning in causation assessment, since both theories are acknowledged by the scientific community (Coggiola, 2013, pp. 331-332). Moreover, if the traditional "but for test" is applied, it would be generally very difficult or even impossible for the plaintiff to prove anything.

The Italian general rule on civil liability provides that the defendant can be held liable if there is a causation link between the defendant's act and the resulting harm. The burden of proof lies with the plaintiff. The existence of a causal link is determined by conditio sine qua non test. In contrast to English courts, the Italian courts never developed a special test for mesothelioma. Moreover, decisions are quite inconsistent with each other (Coggiola, 2013, pp. 334).

The criteria used to ascertain the liability can be roughly divided into three main categories. 1) By excluding the possibility that the mesothelioma was caused by another factor, especially in cases where the only known exposure was the one caused by the defendant. 2) If the existence of other possible causes could not be excluded with certainty, the judge can hold the defendant liable because he believes that there is a high probability that workplace exposure was critical. 3) Lastly, the Corte di Cassazione on two occasions affirmed that the defendant is liable when he failed to provide safety measures sufficient to reduce the mesothelioma risk. The causation link must be examined by assessment of the provided measures (Coggiola, 2013, pp. 334). 
The diversity of the solutions applied by the Italian civil courts generates uncertainties, so victims seek protection in a more comfortable criminal procedure. Similarly, defendants are unable to predict the volume of their future financial obligations toward their insurers.

The relationship between scientific theories and the Italian judicial reasoning was tricky. The scientific expert affirm that the mesothelioma is notoriously caused by asbestos and that all dead workers must have been exposed to it in the factory during workhours. Following this opinion, the Corte di Appello adhered to the multi-fiber theory, the prolonged exposure and poor working conditions. Extended exposure had heightened the risk of mesothelioma and therefore could be regarded as the concurrent cause of the deaths. In the words of the Corte di Appello, this judgment was not the consequence of a concrete scientific assessment, but the result of reasonable adherence to a scientific theory. The defendant appealed. The Cassazione concluded that when two contrasting scientific theories are present (the multi-fiber vs. single-fiber theory), the judge must exclude alternative causes and must verify the scientific theory reliability (Coggiola, 2013, pp. 335-336).

Scientific theories are mere instruments to prove facts. When faced with contrasting scientific theories, the judge must explain the motives for selection, based on the following parameters: the epistemological reasoning must be dialectic to the outcome; the judge does not create the natural laws but simply discoverers them; the causation must be without any reasonable doubt. Three principles are important: first, the judge must evaluate scientific opinions critically and not passively; second, the judge's duty is to apply the scientific rules, not to work them out; third, there must be no reasonable doubt whether the causation is science-based. Hence, the judge must clearly justify his choices (Coggiola, 2013, pp. 337). The mentioned decision of the criminal branch of the Corte di Cassazione will most probably have no influence in civil cases (Coggiola, 2013, pp. 339).

The complexity of the contemporary world increasingly requires the employment of scientific theories in law. Judges are frequently obliged to ask for expert scientific opinions and explanations. This creates a risk of uncritical scientific theory adoption rather than the autonomous judicial decision (Coggiola, 2013, pp. 338).

\section{THE NETHERLANDS LAW}

A plaintiff needs to prove the causal link between the tortfeasor's wrongful conduct and the damage: the question is whether the damage would not have occurred if the tortfeasor had followed the relevant norm in question (employer's duty of care). If the answer to this question is positive, then the causal connection does exist (conditio sine qua non). Traditionally, if a wrongful act is not conditio sine qua non, causality cannot be established; thus, the claim will be dismissed (Samii, 2013, p. 347). 
An asbestos victim is usually unable to establish causation due to multiple possible sources or a large degree of uncertainty. The provision of Article 7:658 of the Civil Code, as well as the general tort clause of Article 6:162, traditionally adhere to an all-or-nothing rule, effective in its simplicity and legal certainty. According to the all-or-nothing rule, the employee cannot be awarded any compensation when conditio sine qua non is not established. Hence, the risk of uncertainty is completely shifted to the employee. A contradictory situation is equally conceivable, in which an employer is held liable for the whole damage, in spite of a great likelihood that part of the damage is attributable to non-occupational environmental exposure (Samii, 2013, pp. 348, 354, 358). Since both extremes are neither just nor reasonable, the Dutch law has sought alternatives to the traditional all-or-nothing rule.

\section{THE EMPLOYER'S LIABILITY}

Article 7:658 of the (New) Civil Code, puts a clear obligation on the employer to protect his employees from workplace harm (Samii, 2013, pp. 349). The plaintiff must prove that the damage is connected to earlier employment (the requirement of functional connection). Case law concerning asbestos liability has elaborated this rule. Firstly, the victim needs to prove that, at some point during employment, he was actually exposed to asbestos. Secondly, the protection of the weaker party is echoed in the case law. The proof of functional connection has been eased in favour of the employee. The causation is presumed if the employer has failed to take the adequate measures to avoid harm. Practically, the employee is only required to prove that he was exposed and that this exposure could be the cause of illness (Samii, 2013, pp. 351-352).

The employer can avoid liability by proving that he has taken the reasonably expected safety measures. Before 1960, the link between asbestos and mesothelioma was not known, the disease was not yet recognized, therefore the employer was unable to take the appropriate safety measures in order to prevent this concrete harm. The Supreme Court rejected this argument as it was well-known that asbestos is dangerous, even though mesothelioma was an unknown risk (Samii, 2013, pp. 352).

In contrast to this, in another case, the exposure was relatively short and the employer did not actually produce or use of asbestos. The Supreme Court accepted these arguments and found that the employer had sufficiently proven the lack of fault. Similarly, the employer can avoid liability if harm was caused by the employee's willful intent or conscious recklessness, or is the result of non-workspace exposure. This is in fact the disproving of the conditio sine qua non connection, by demonstrating that the damage would have occurred despite the employer taking adequate safety measures (Samii, 2013, pp. 354). 
Case law on occupational asbestos liability shows that the courts rarely leave the employee empty-handed. Nefalit v. Karamus has been one of the most ground-breaking precedents in the Dutch civil law, with farreaching consequences (Nefalit v. Karamus, 2006). During his employment by Nefalit, Karamus, a smoker, had been exposed to asbestos, and later contracted lung cancer. He claimed damages, based on the employer's liability under Article 7:658 Civil Code. Scientifically, it was not possible to establish which of the various possible causes - asbestos, smoking, a physical condition, or background risks - had led to the cancer. Nonetheless, a certain degree of probability that asbestos was indeed the cause remained plausible. An expert estimated this probability to be $55 \%$. Nefalit argued that long term smoking was the principal cause. The Court ordered the employer to compensate the employee, while reducing his duty proportionally, since the employee has also contributed to his own condition. Hence, the employer was ordered to compensate $55 \%$ of the damage. This case opened the gates for the proportional liability in Dutch tort law (Samii, 2013, pp. 354-356).

\section{NON-OCCUPATIONAL ASBESTOS LIABILITY}

The article 6:162 Civil Code is a negligence-based liability provision, meaning that for liability to arise, there must be an unlawful damaging act, attributed to the wrongdoer. Any conduct is unlawful if it infringes on someone's right, is in violation of the statuary duty of care, or even against an unwritten rule. In contrast to occupational victims, the victims of domestic or environmental asbestos exposure who claim compensation under Article 6:162 Civil Code are in a considerably less favorable legal position. First of all, the burden of proof of fault lies with the claimant, who must prove that the defendant was aware of the hazard involved (Samii, 2013, pp. 360).

In one case the former pupil alleged that the school exposed him to the carcinogenic substance. The school argued that the asbestos in the building was completely sealed off and was not damaged; hence, the former pupil could not have contracted the illness during the time spent at the school. The court held that the causal link was consequently not established. The claim was dismissed, the school's conduct was not wrongful (Samii, 2013, pp. 362).

However, thanks to case law, there is a reversal of the burden of proof regarding causation, the so-called "omkeringsregel." It is a rebuttable presumption that, when a norm which prevents a specific danger has been breached, and the risk is significantly engorged by that violation, the causal link between the breach and the damage suffered is presumed. Based on reasonableness and fairness, the "omkeringsregel" provides that whenever a wrongful act creates or increases a certain risk of damage which actually materializes, the causal link is assumed. The wrongdoer can make plausible 
that even if he had not acted wrongfully, the damage would nevertheless have occurred (Samii, 2013, pp. 361).

Based on reasonableness and fairness and in line with Karamus $v$. Nefalit, it seems unacceptable that the risk of causal uncertainty is completely shifted to either the employee or the employer. The full compensation would be out of the question according to the traditional Dutch law. Because of the all-or-nothing approach, claims, such as that in the case of Sienkiewicz, would be unsuccessful. Both the English and Dutch law thus provide the victims with compensation, albeit in significantly varying degrees. The position of mesothelioma victims is stronger under the English law, though. (Samii, 2013, pp. 369).

The adoption of proportional liability has been a ultimate achievement. The traditional all-or-nothing approach is neither logical nor it provides for a desired solution. It is therefore more reasonable to spread the damages onto parties in proportion to the degree of co-responsibility. Proportional liability is just, and in accordance with the Principles of European Tort Law (Samii, 2013, pp. 370).

\section{CONCLUDING REMARKS}

Responding to divergent national practice, the Principles of European Tort Law (PETL) offer well-grounded solutions for uncertain causality, deducted from asbestos litigations. These are presented in three different hypotheticals, and could be used in Serbian or any other national practice.

Scenario 1: Multiple tortfeasors, where each wrongful contribution was sufficient to cause damage. An employee is exposed to workplace asbestos with successive employers. He subsequently develops mesothelioma and brings an action for damages. It was uncertain which of the several persons had caused the damage, but the causation by these persons was certain. It is impossible for the employee to prove who of the successive employers particularly and most significantly contributed to his illness. He is thus unable to prove that, in the absence of the exposure during concrete engagement, he would not have fallen ill (Zimmermann \& et al, 2007, pp. 386). The standard conditio sine qua non test fails.

Art. 3:103 PETL contains the provision on Alternative Causes (1) that reads: "In case of multiple activities, where each of them alone would have been sufficient to cause the damage, but it remains uncertain which one in fact caused it, each activity is regarded as a cause to the extent corresponding to the likelihood that it may have caused the victim's damage."

Under this provision, it is enough to prove that the risk to which the worker was exposed by any employer was sufficient to cause the disease, since the scientific evidence states that single exposure is sufficient. All employers are liable, each of them to the extent determined by the duration and intensity of exposure (Zimmermann \& et al, 2007, pp. 387). 
The case in which all contributions were necessary to cause the damage may, however, also be analyzed under Art. 9:101 (3) PETL. When there is reasonable basis for attributing only a part of damage, each person is liable only for the part of the damage attributable to him. Although the damage (cancer) is indivisible, the periods of the employees' exposure to asbestos by the employers are different and well known. Thus, the employers' liability would not be solidary but proportional.

However, if the damage did not result from a single exposure but the exposure of all employers was necessary for the risk to materialize (cumulative effect), each employer's activity would be a conditio sine qua non for the damage. The employers would then be liable in solidum, under Art. 9:101 (1) 2 b) PETL: "Liability is solidary where [...] one person's independent behavior or activity causes damage to the victim and the same damage is also attributable to another person" (Zimmermann \& et al, 2007, pp. 386).

Scenario 2: A single tortfeasor and the victim's contribution. $\mathrm{V}$ is exposed to asbestos during his work. This exposure amounts to 35 fiber years (measure for relative extent of exposure). Besides, he has been smoking from age 17 onwards, around 20 cigarettes a day. $\mathrm{V}$ dies from lung cancer. The exposure to asbestos can lead to cancer, and the same is true for smoking. Given the 35 fiber years, the chance that $\mathrm{V}$ became ill because of the asbestos was $26 \%$ (Zimmermann \& et al, 2007, pp. 435).

It is impossible to establish with certainty whether the damage is due to the asbestos or smoking. According to Art. 3:103 (1) PETL, "activities" include activities within the victim's own sphere. This leads to a proportional distribution of the loss between a tortfeasor and the victim. Each of the causes alone (asbestos or smoking) would have been sufficient to cause the damage, but it remains uncertain which one caused it for real. Therefore, the employer is liable for $26 \%$ of damage (Zimmermann \& et al, 2007, p. 435).

Scenario 3: Multiple tortfeasors and environmental exposure. An employee is exposed to asbestos during his employment with successive employers. He develops a fatal cancer and brings an action for damages. The mesothelioma is most probably caused by workplace exposure, however, a small risk might result from environmental exposure as well (Zimmermann \& et al, 2007, pp. 538).

As seen in Scenario 1, the employers are liable proportionally. Can they ask for a reduction because of environmental exposure? The probability that the disease was caused by natural events is a circumstance within the victim's sphere (Art. 3:106 PETL). However, one must quantify this low risk in order to take it into consideration. If the probability that the damage was caused by environmental exposure was $2 \%$, it would reduce the employers' liability to $98 \%$. However, many European courts prefer to ignore very small risks as long as considerably high risk can be identified (Zimmermann \& et al, 2007, pp. 539). 


\title{
REFERENCES
}

Barker v Corus (UK) plc (2006) UKHL 20

BGB: Bürgerliches Gesetzbuch BGBl. I S. 42, 2909; (2003) I S. 738. 31. Januar BGBl. I S. 54 (2019)

Busnelli, F. D., Comandé, G., Cousy, H., Dobbs, D. B., Dufwa, B. W., Faure, M. G., Gilead, I., ... Widmer, P. (2005). Principles of European Tort Law: Text and Commentary. Vienna: Springer Vienna.

Coggiola, N. (2013). Causation in Mesothelioma Cases in the Italian Courts. European Review of Private Law, 21(1), 331-339.

Fairchild v Glenhaven Funeral Services Ltd (2002) UKHL 22

G'Sell, F. (2017). Alternative Causation under French Law. European Review of Private Law, 25(6), 1109-1115.

NBW: Nieuwe Burgerlijk Wetboek. Nederland. 1 januari (1992)

Nefalit/ Karamus, Hoge Raad 31 maart 2006 (ECLI:NL:HR:2006:AU6092)

Samii, S. M., \& Keirse, A. (2013). Taxonomy of Asbestos Litigation in the Netherlands: Duelling with Causal Uncertainty. European Review of Private Law, 21(1), 341-370.

Sienkiewicz v Greif (2011) UKSC 10

Vandenbussche, W. (2017). Alternative causation in asbestos cases under Belgian law. European Review of Private Law, 25(6), 1141-1151.

Wagner, G. (2013). Asbestos-Related Diseases in German Law. European Review of Private Law, 21(1), 319-329.

Zimmermann, R., Winiger, B., Koziol, H., \& Koch, B. A. (2007). Digest of European Tort Law, Bd. I: Essential Cases on Natural Causation. Springer Wien New York. 2007. ISBN 978-3-211-36957-9.

\section{АЛТЕРНАТИВНИ КАУЗАЛИТЕТ У ОДШТЕТНОМ ПРАВУ}

\author{
Михајло Цветковић \\ Универзитет у Нишу, Правни факултет, Ниш, Србија
}

\section{Резиме}

Заснивање одговорности за проузроковану штету захтева постојање узрочне везе између штетне радње и негативних последица. Мада је у највећем броју случајева узрочна веза очигледна, постоје ситуације када је њено утврђивање сложено зато што има више потенцијалних узрока, односно постоји временска или просторна удаљеност између штетног догађаја и штете. Такви проблеми погодили су многобројне жртве чије је здравље озбиљно нарушено услед канцерогеног дејства азбеста. Пун обим штетног утицаја азбеста откривен је тек након његове дугорочне и масовне употребе широм Европе. Оштећени су се суочили са проблемом утврђивања и доказивања узрочне везе. Најтеже су погођени запослени оболели након вишегодишњег излагања код различитих послодаваца. Ниво медицинских и научних сазнања није био задовољавајући, те није било јасно да ли је мезотелиом (фатални канцер) изазван једнократним излагањем или кумулативним утицајем. Традиционална решења одштетног права нису обезбедила правичну накнаду. Класични „sine qua non” тест узрочности био је неприкла- 
дан јер је свако од послодаваца могао да приговори да се излагање догодило док је запослени био на раду код неког другог послодавца, или да је жртва својим понашањем допринела штети, или да је узрок атмосферски азбест. Осим тога, принцип „све или ништа” приликом одлучивања о накнади доводио је туженог или тужиоца у несразмерно неповољан положај. Зато се у парницама поводом азбеста развило учење о алтернативном каузалитету. Диференцирали су се различити приступи према томе да ли се ради о професионалном обољењу или је у питању неуговорна одговорност. Судови су напустили традиционални тест узрочности, окренули терет доказивања у корист жртве, ослонили се на вероватноћу, што је омогућило бољу расподелу одговорности, и увели претпоставке да би олакшали одлучивање. Донети су посебни прописи, формирани су фондови за обештећење, јавила су се нова тумачења старих института, као што је одговорност за другог. Судска пракса и доктрина настали поводом азбеста расветлили су тако најсложенију област одштетног права - узрочност. Најбоља решења европске јуриспруденције објединила су „Начела европског одштетног права”, где су поједине одредбе намењене управо замршеним случајевима као што су: конкурентни, потенцијални, кумулативни, престижући и алтернативни каузалитет. Познавање алтернативног каузалитета корисно је у сложеним споровима када више штетника узрокује исту штету; када се неки узроци везују за самог оштећеног, односно постоје узроци невезани за штетнике, што је врло значајно за медицинску, еколошку и саобраћајну одговорност. Нема јединственог решења. Док је за неке ситуације најприкладнија солидарна одговорност, у другим се истиче пропорционална, мада се и њој могу ставити замерке. Са развојем егзактне науке, проблем природне узрочности ће се смањивати, али јуристички каузалитет остаје зависан од нормативних циљева и политике обештећења. 